\title{
Role of Cytokines, Endotoxins (LPS), and Lipoteichoic Acid (LTA) in Endodontic Infection
}

\author{
Abhishek Parolia ${ }^{1 *}$, Lo S Gee ${ }^{2}$, ICC de Moraes Porto ${ }^{3}$ and Mandakini Mohan ${ }^{4}$ \\ ${ }^{1}$ School of Dentistry, International Medical University, Bukit Jalil, Kuala Lumpur, Malaysia \\ ${ }^{2}$ Department of Biomedical Science, School of Medicine, International Medical University, Bukit Jalil, Kuala Lumpur, Malaysia \\ ${ }^{3}$ Department of Restorative Dentistry, School of Dentistry, Federal University of Alagoas, Maceió, Alagoas, Brazil \\ ${ }^{4}$ School of Dentistry, International Medical University, Bukit Jalil, Kuala Lumpur, Malaysia
}

Received: September 04, 2014; Accepted: November 219, 2014; Published: December 03, 2014

*Corresponding author: Abhishek Parolia, Senior Lecturer, School of Dentistry, International Medical University, Bukit Jalil 57000, Kaula Lampur, Malaysia, Tel: 00-011-293-227; E-mail: abhishek_parolia@imu.edu.my

\begin{abstract}
The most common etiological factor for pulpal and periapical disease is microorganisms. Apical periodontitis is considered as an inflammatory reaction in the peri-apical tissues to the presence of micro-flora and their components within the root canal system. The composition of micro-flora of root canal has been studied extensively over the years and the presence of gram-positive, gramnegative bacteria and their components are considered to be the main reason for endodontic treatment failure. Bacterial components such as Lipopolysaccharide (LPS) and Lipoteichoic Acid (LTA) can enter the peri-apical tissue and initiate the inflammatory process by increasing the level of cytokines. Therefore, this review was done to understand the role of Lipopolysaccharide (LPS), Lipoteichoic acid (LTA) and cytokines in endodontic infection and study their relationship between each other. Data from various resources were gathered and analyzed. The activation pathway and biological effects of cytokines were also studied and it was observed that cytokines especially TNF- $\alpha$ (Tumour Necrosis Factor), IL-1 $\beta$ (Interleukin), IL-6 and IL-8 are up-regulated as a consequence of the immune response generated against the LPS and LTA. Chemokines CXCL2 (Chemokine (C-X-C motif) ligand) and CXCL10 were also shown to have increased level due to the presence of LTA. Cytokines are required to combat the foreign material during an infection, but when the level of cytokines is too high, it can cause injuries to the host itself through peri-apical bone destruction. More studies should be carried out in order to better understand the significance of each cytokine during an endodontic infection and to improve the treatment given for the patients depending on their infection status.
\end{abstract}

Keywords: Cytokines; Endotoxins; Lipoteichoic Acid; Endodontic Infection

\section{Introduction}

Bacteria and their byproducts are considered to be the major cause of pulpal and peri-apical diseases [1,2]. Therefore, their elimination is one of the most important steps in root-canal treatment. In most cases failure of root-canal treatment occurs when treatment procedures have not met a satisfactory standard for control and elimination of infection [3]. The association of bacterial species with specific clinical conditions has been investigated in a number of studies and it has been reported that bacterial species recovered from asymptomatic teeth are different from that isolated from clinically symptomatic teeth [4-7] and from primary infection to that of failed endodontic treatment [8-11]. Primary infected root canals are untreated canals, where microorganisms are able to access and colonize the pulpal tissue and progresses to cause apical periodontitis. The root canal microbiota responsible for primary infection is mainly mixed, comprising gram-negative and gram-positive and mostly anaerobic microorganisms. On the other hand, persistent intraradicular or secondary infections are the major causes of the failure of root-canal treatment and facultative anaerobic, gram-positive bacteria predominate in the canals with failed endodontic treatment [11-13]. It is generally believed that persisting gram-positive bacteria in root canals have ability to survive under harsh, nutrient-limited conditions of the root-filled teeth $[13,14]$. These gram-positive and gram-negative bacteria contain various virulence factors including Lipoteichoic acid (LTA), Lipopolysaccharide (LPS), peptidoglycan, aggregation substance, surface adhesions, sex pheromones, lytic enzymes such as gelatinase, hyaluronidase and cytolysin, responsible for survival of these microorganisms in a very harsh environment of the root canal system [15]. Each of these factors may be associated with various stages of endodontic infection as well as peri-apical infection. Among the virulence factors, LTA, a glycerol phosphate surface polymer, seems to have high pathogenic potential similar to Lipopolysaccharide (LPS) (i.e. endotoxin) released from gram-negative bacteria [16]. LTA from gram-positive bacteria acts as an adhesion molecule binds to host cells via its lipid moiety and promote bacterial colonization and invasion. It acts as a stimulator of respiratory burst and exocytosis of lysosomal enzymes, as an inducer of nitric oxide and cytokines, as a mitogen for T cells, and as a transcription factor [17]. LTA can also synergise with peptidoglycan and in mixed bacterial infections, also with lipopolysaccharide to induce generation of nitric oxide and cytotoxic cytokines [18]. LPS and LTA activate the innate immune system by similar mechanisms. Both LPS and LTA bind to CD14, activate signaling by Toll-Like Receptors 
(TLRs), and induce proinflammatory cytokines such as Tumor Necrosis Factor alpha (TNF- $\alpha$ ), Interleukin-1 (IL-1), Interleukin8 (IL-8), Interleukin-12 (IL-12), and anti-inflammatory cytokine interleukin-10 (IL-10) $[19,20]$. Studies have demonstrated that LTA induces bone resorption [21], TNF- $\alpha$ production by TLR 2 (Toll-like receptor 2) [22], apoptosis of cultured pulp cells (mainly fibroblasts) that contributes to the initiation of and/or progression of pulpitis [23], exhibits high potency in the induction and rapid rise of macrophage Vascular Endothelial Growth Factor (VEGF) expression [24,25] that may lead to pulpal necrosis or even to the maintenance of the inflammatory reaction after root canal therapy. Today, the term 'endotoxin' is used synonymously with the term lipo-polysaccharide, which is a major constituent of the outer cell wall of gram-negative bacteria. LPS is considered the major etiological component responsible for pathophysiology of inflammation and post infectious sequelae. Correlations have been found between the high concentration of LPS content of infected root canals and clinical endodontic symptoms such as spontaneous pain, tenderness to percussion, exudation and periapical radiolucent areas $[26,27]$ but not much importance is given to LTA content present in the infected canals, which can also lead to severe inflammation and tissue damage. There are findings that do not clearly support the role of LTA as a major virulence factor because quantities of the LTA (microgram to milligram) necessary to induce generation of proinflammatory agonists are many times greater than those of lipopolysaccharide (nanogram) [17]. Although lipopolysaccharide is almost the exclusive virulence factor in gram-negative organisms, those that are gram-positive can induce tissue damage by elaborating many cytotoxic factors, of which LTA would be only one. The literature has indicated that the success of re-treatment of teeth with apical periodontitis is lower with an overall success rate of $66 \%$ [28].This poorer prognosis in root-canal re-treatments is associated with difficulties in the elimination of the particular microorganism in cases of root-canal treatment failure because different strains from the same bacteria species can present variations in their virulence and resistance influencing the treatment outcome. Therefore, a thorough knowledge of virulent microorganism present in failed endodontic cases is necessary to guide new strategies to combat infection, leading to a better prognosis for root-canal re-treatments. Therefore, this review was carried out to understand the role of (LPS), (LTA) and cytokines in endodontic infection and study their relationship between each of them.

\section{Discussion}

The approach of review was taken to compile current best evidences for this review. After formulation of a research question on the role of LPS, LTA and cytokine in an endodontic infection, a comparison was made between data collected from various databases using the Medical subject headings (Mesh) or DeCS vocabulary. The search engines that were utilized for electronic data from the internet were MEDLINE, PUBMED, GOOGLE, and the Cochrane Collaboration Database for original research articles in the English literature published from $1^{\text {st }}$ January 2000 to $31^{\text {st }}$ December 2013, using keywords like endodontic infection, lipopolysaccharide, lipoteichoic acid and cytokine. Search criteria
AND was mostly used to search for more relevant article. Around 58 articles were obtained, with a mixture of journals and books. Inclusion eligibility for the review was determined by specific criteria that are, the paper must be a research paper, published within the past 15 years, with virulence factors (LPS or LTA) and cytokines identified, and must be an endodontic-related infection. Only those that fulfill all these criteria were used in this review. The author, year, virulence factors, cytokines and conclusion of the selected studies are summarized in Table 1. According to the papers selected, TNF- $\alpha$ is the most abundant cytokine that has been detected in endodontic infection, $53 \%$ of the studies detected this cytokine. Generally, both LPS and LTA cause up-regulation of TNF- $\alpha$. Gram negative species tend to induce higher ratio of TNF- $\alpha$ to IL-8. Interleukins especially IL$1 \beta$, IL-6, IL-8, and IL-10 are also increased during the course of endodontic infection. Chemokines such as CXCL2 and CXCL10 are also detected in endodontic infections. The chemokines activate inflammatory cells and also influence angiogenesis. Other than chemokines, LTA is also shown to induce VEGF (Vascular Endothelial Growth Factor) in macrophages up to nine folds.

Cytokines are small signaling molecules that mediate host responses to infection, inflammation, and trauma. Pro-inflammatory cytokines initiate or enhance systemic inflammation while anti-inflammatory cytokines reduce inflammation and promote healing. Examples of proinflammatory cytokines include IL-1 and TNF- $\alpha$ whereas IL-10 is an important anti-inflammatory cytokine. Some cytokines can have both pro-inflammatory and anti-inflammatory properties such as the IL- 6 as it can inhibit TNF- $\alpha$ and IL-1, at the same time activates IL-10. Cytokines work with each other in a homeostatic network regulation to prevent the constant state of inflammation. In endodontic infection; gram-negative bacteria contribute a high percentage of LPS, a primary virulence factor [29-39]. Murakami et al. [29] detected P.endodontalis LPS in $90 \%$ of the samples obtained from patients with acute abscesses. LPS is also known as endotoxins, it forms an integral part of cell wall of gram-negative bacteria [40]. The LPS molecule consists of $\mathrm{O}$-antigen, core oligosaccharide, and a glycolipid component named lipid A [30].These endotoxins are released during bacteria multiplication and after cell death [40]. Similarly, LTA is the main virulence factor of gram positive bacteria. It is an amphiphilic molecule consisting of a poly-glycerolphosphate with a complex glycolipids group attached to it [17]. LPS activates mammalian cells by first binding with Lipopolysaccharide Binding Protein (LBP) in the serum. Subsequently, LBP presents LPS to the CD14/TLR4/MD2 receptor complex. This receptor complex is present on cells like-neutrophils, macrophages, dendritic cells and endothelial cells $[18,22]$. This interaction activates an intracellular signal transduction cascade, resulting in secretion of inflammatory cytokines. Gram positive bacteria trigger similar cascade by mediating ligands through TLR2 instead of TLR4 [5,23].According to Tietzeet al. [31], Gram negative species tend to induce higher levels of TNF- $\alpha$ than IL-8. However, evidences have shown that $P$. gingivalis is an exception for this presumption as it has similar activity with the gram-positives. This is due to the heterogeneity of the species' lipid A molecule 
Table 1: Summary of the studies selected.

\begin{tabular}{|c|c|c|c|c|c|}
\hline Ref & Year & Author & Title & $\begin{array}{l}\text { Virulence factor } \\
\text { and cytokines }\end{array}$ & Conclusion \\
\hline 29 & 2001 & Murakami et al. & $\begin{array}{l}\text { A possible mechanism of } \\
\text { maxillofacial abcess formation: } \\
\text { involvement of } \\
\text { Porphyromonasendodontalis } \\
\text { lipopolysaccharide } \\
\text { via the expression of } \\
\text { inflammatory cytokines }\end{array}$ & \begin{tabular}{|l} 
Porphyromonasend- \\
odontalis LPS \\
TNF- $\alpha$, IL-1 $\beta$
\end{tabular} & $\begin{array}{l}\text { LPS of the bacteria is present in the bacterially } \\
\text { infected root canal fluid of about } 90 \% \text { of the } \\
\text { patients. The ability of LPS to induce cytokines } \\
\text { was reduced by incubating the macrophages with } \\
\text { antibodies against the bacterial LPS. ELISA showed a } \\
\text { significantly high level } \\
\text { of TNF- } \alpha \text { to be present in the infectious materials. }\end{array}$ \\
\hline 30 & 2001 & Gutsmann et al. & $\begin{array}{l}\text { Dual Role of LBP in Neutralization } \\
\text { of LPS and Enhancement of } \\
\text { LPS-Induced Activation of } \\
\text { Mononuclear Cells (MNC) }\end{array}$ & $\begin{array}{l}\text { LPS } \\
\text { IL-1,IL-6, TNF- } \alpha\end{array}$ & $\begin{array}{l}\text { LBP level rises after acute-phase response due to the } \\
\text { activation by IL-1 and IL-6. } \\
\text { LPSs activate monocytes and macrophages to } \\
\text { secrete TNF- } \alpha \text { and IL-1, etc. LBP present as a soluble } \\
\text { protein and also as a transmembrane protein of } \\
\text { MNC. Low concentrations of LBP enhance the LPS- } \\
\text { induced activation of MNC, whereas the acute-phase } \\
\text { rise in LBP concentrations inhibits LPS-induced } \\
\text { cellular stimulation. }\end{array}$ \\
\hline 25 & 2003 & Telles et al. & $\begin{array}{l}\text { Lipoteichoic Acid Up-regulates } \\
\text { VEGF Expression in Macrophages } \\
\text { and Pulp Cells }\end{array}$ & $\begin{array}{l}\text { LTA } \\
\text { VEGF }\end{array}$ & $\begin{array}{l}\text { LTA induced up to a 9-fold increase in VEGF protein } \\
\text { expression in macrophages. LTA is sufficient to } \\
\text { induce expression of a pro-angiogenic factor. }\end{array}$ \\
\hline 31 & 2006 & Tietze et al. & $\begin{array}{l}\text { Differences in innate } \\
\text { immune responses upon } \\
\text { stimulation with gram positive } \\
\text { and gram-negative } \\
\text { bacteria }\end{array}$ & $\begin{array}{l}\text { LTA, LPS, } \\
\text { TNF- } \alpha, \text { IL-8 }\end{array}$ & $\begin{array}{l}\text { Gram negative species produced higher amounts of } \\
\text { TNF- } \alpha \text { while gram positive species produced higher } \\
\text { amount of IL- } 8 \text { due to the activation of different } \\
\text { TLRs. } \\
\text { Purified gram-negative and gram-positive products } \\
\text { may not mimic the response to whole pathogen. }\end{array}$ \\
\hline 32 & 2006 & Durand et al. & $\begin{array}{l}\text { Lipoteichoic Acid Increases } \\
\text { TLR and Functional Chemokine } \\
\text { Expression while Reducing Dentin } \\
\text { Formation in Odontoblasts }\end{array}$ & $\begin{array}{l}\text { LTA } \\
\text { Chemokines CXCL2 }\end{array}$ & $\begin{array}{l}\text { TLR trigger secretion of pro-inflammatory } \\
\text { chemokines and cytokines that activate blood borne } \\
\text { inflammatory cells. CCL2 is the key chemokine } \\
\text { produced during microbial infection. Chemokines } \\
\text { also influence angiogenesis. }\end{array}$ \\
\hline 33 & 2007 & Adachi et al. & $\begin{array}{l}\text { Caries-related Bacteria } \\
\text { and Cytokines Induce } \\
\text { CXCL10 in Dental Pulp }\end{array}$ & $\begin{array}{l}\text { LTA, } \\
\text { CXCL10 }\end{array}$ & $\begin{array}{l}\text { HDPF stimulated with PGN, but not LTA, were able } \\
\text { to produce CXCL10. }\end{array}$ \\
\hline 34 & 2008 & Staquet et al. & $\begin{array}{l}\text { Different Roles of Odontoblasts } \\
\text { and Fibroblasts in Immunity }\end{array}$ & $\begin{array}{l}\text { LTA } \\
\text { CXCL2 and CXCL10 }\end{array}$ & $\begin{array}{l}\text { CXCL2 and CXCL10 were thus increased by LTA only } \\
\text { in odontoblast-like cells }\end{array}$ \\
\hline 35 & 2008 & Baik JE et al. & $\begin{array}{l}\text { Lipoteichoic Acid Partially } \\
\text { Contributes to the Inflammatory } \\
\text { Responses to Enterococcus } \\
\text { faecalis }\end{array}$ & LTA, TNF- $\alpha$ & $\begin{array}{l}\text { LTA of } E \text {. faecalis stimulate macrophage to produce } \\
\text { significant high level of TNF- } \alpha \text { and nitric oxide. } \\
\text { LTA also stimulate production of inflammatory } \\
\text { mediators. } \\
\text { LTA stimulate TLR2 but not TLR4. }\end{array}$ \\
\hline 36 & 2009 & Soden et al. & $\begin{array}{l}\text { Angiogenic Signaling Triggered } \\
\text { by Cariogenic Bacteria } \\
\text { in Pulp Cells }\end{array}$ & LTA, VEGF & $\begin{array}{l}\text { LTA induces VEGF upregulation in pulp cells via } \\
\text { P13K-Akt signaling }\end{array}$ \\
\hline 37 & 2012 & Kraus et al. & $\begin{array}{l}\text { Interactions of Adiponectin and } \\
\text { Lipopolysaccharide from } \\
\text { Porphyromonas gingivalis }\end{array}$ & $\begin{array}{l}\text { LPS, IL-1 } \beta, \text { IL-6, IL- } \\
8, \text { IL-10 }\end{array}$ & $\begin{array}{l}\text { LPS significantly up-regulate IL-1 } \beta \text {, IL-6, IL-8, IL-10 } \\
\text { expressions. }\end{array}$ \\
\hline 38 & 2012 & Maciel et al. & $\begin{array}{l}\text { Cytokine expression in response } \\
\text { to root canal infection in } \\
\text { gnotobiotic mice }\end{array}$ & $\begin{array}{l}\text { Fusobacteriumnu- } \\
\text { cleatum, Peptostrep- } \\
\text { tococcus prevotii } \\
\text { IFN-g, TNF- } \alpha \text {, IL-10, } \\
\text { IL- } 4 \text {, TGF-b }\end{array}$ & $\begin{array}{l}\text { Different bacteria have different effect on cytokines } \\
\text { levels. F. nucleatum causes increase in IFN-g, TNF- } \alpha \text {, } \\
\text { IL- } 4 \text {. IL-10 is induced by either one of the two } \\
\text { bacteria. TGF-b is induced by combination of the } \\
\text { two bacteria. }\end{array}$ \\
\hline
\end{tabular}


which can activate both TLR 2 and $4[9,10]$.Therefore, the types of cytokines released should depend on the TLR activated instead of the Gram stain of the bacterial species. Studies revealed that the cytokines induced by LPS and LTA shares a wide range of pathophysiological effects, depending on the type of cytokine. However, the potency of LTA in inducing cytokine release is 100- to 1000- folds lower compared to LPS [19]. These cytokines are associated with pulp and peri-apical inflammation as well as activation of complement system to eradicate the pathogens. Specifically, TNF- $\alpha$, IL-1 $\beta$ and IL- 6 are important mediators during acute phase of inflammation. However, if the homeostasis of cytokines is not achieved, there will be fibrosis and necrosis of the pulp. This is because cytokines can activate neutrophils and macrophages to produce reactive oxygen, nitrogen species, and cytotoxic cytokines that may cause cell damage [24]. Besides, cytokines like Vascular Endothelial Growth Factor (VEGF) will cause angiogenesis and swelling in pulp cavity $[2,25]$. Eventually, the vessels will be damaged. Osteomyelitis and periapical bone destruction can also take place. Although LPS is known to induce the production of cytokines, the amount of cytokines can be lowered to control inflammation by conferring 'LPS tolerance' to the immune cells. This can be done by exposing the immune cells to low doses of LPS [26]. The ability to develop tolerance is also better in young compared to older adults [4].

\section{Conclusion}

The present work provides insight about the role of LPS and LTA in the initiation of immune responses that occur in human dental cavity. By analyzing the evidences and studies carried out, a positive association was found between LPS and LTA with cytokines. Results from the various studies showed that certain inflammatory cytokines especially TNF- $\alpha$, IL-1 $\beta$, IL- 6 and IL-8 are up-regulated in endodontic infections. Although the cellular responses caused by cytokines are usually beneficial, they might also harm the host through septic shock due to overproduction of cytokines.

\section{References}

1. Takahashi K. Microbiological, pathological, inflammatory, immunological and molecular biological aspects of periradicular disease. IntEndod J. 1998; 31(5): 311-25.

2. Kakehashi S, Stanley HR, Fitzgerald RJ. The effects of surgical exposures of dental pulps in germ-free and conventional laboratory rats. Oral Surg Oral Med Oral Pathol. 1965; 20(3): 340-49.

3. Nair PN, Sjogren U, Fidgor D, Sundqvist G. Persistent periapicalradiolucencies of root-filled human teeth, failed endodontic treatments, and periapical scars. Oral Surg Oral Med Oral Pathol Oral Radiol Endod. 1999; 87(5): 617-27.

4. Yoshida M, Fukushima H, Yamamoto K, Ogawa K, Toda T, Sagawa H. Correlation between clinical symptoms and microorganisms isolated from root canals of teeth with periapicalpathosis. J Endod. 1987; 13(1): 24-8.

5. Gomes BP, Drucker DB, Lilley JD. Association of specific bacteria with some endodontic signs and symptoms. Int Endod J 1994; 27(6): 29198.

6. Gomes BP, Lilley JD, Drucker DB. Associations of endodontic symptoms and signs with particular combinations of specific bacteria. Int Endod J. 1996; 29(2): 69-75.

7. Siqueira JF Jr, Rôças IN, Rosado AS. Investigation of bacterial communities associated with asymptomatic and symptomatic endodontic infections by denaturing gradient gel electrophoresis fingerprinting approach. Oral Microbiol Immunol. 2004; 19(6): 36370.

8. Sassone LM, Fidel RA, Faveri M, Guerra R, Figueiredo L, Fidel SR, et al. A microbiological profile of symptomatic teeth with primary endodontic infections. J Endod. 2008; 34(5): 541-5. doi: 10.1016/j. joen.2008.02.004.

9. Peciuliene V, Balciuniene I, Eriksen HM, Haapasalo M. Isolation of Enterococcus faecalis in previously root-filled canals in a Lithuanian population. J Endod. 2000; 26(10): 593-95.

10. Gomes BP, Pinheiro ET, Jacinto RC, Zaia AA, Ferraz CC, Souza-Filho FJ. Microbial analysis of canals of root-filled teeth with periapical lesions using polymerase chain reaction. J Endod. 2008; 34(5): 537-40. doi: 10.1016/j.joen.2008.01.016.

11.Gomes BP, Pinheiro ET, Gadê-Neto CR, Sousa EL, Ferraz CC, Zaia AA, et al. Microbiological examination of infected dental root canals. Oral Microbiol Immunol. 2004; 19(2): 71-6.

12. Pinheiro ET, Gomes BP, Ferraz CC, Sousa EL, Teixeira FB, Souza-Filho FJ. Microorganisms from canals of root-filled teeth with periapical lesions. Int Endod J. 2003; 36(1): 1-11.

13. Sundqvist G, Figdor D, Persson S, Sjogren U. Microbiologic analysis of teeth with failed endodontic treatment and the outcome of conservative re-treatment. Oral Surg Oral Med Oral Pathol Oral Radiol Endod. 1998; 85(1): 86-93.

14. Siqueira JF Jr, Rocas IN. Polymerase chain reaction-based analysis of microorganisms associated with failed endodontic treatment. Oral Surg Oral Med Oral Pathol Oral Radiol Endod. 2004; 97(1): 85-94.

15. Stuart CH, Schwartz SA, Beeson TJ, Owatz CB. Enterococcus faecalis: its role in root canal treatment failure and current concepts in retreatment. J Endod. 2006; 32(2): 93-98.

16. Wisplinghoff H, Seifert H, Tallent SM, Bischoff T, Wenzel RP, Edmond MB. Nosocomial bloodstream infections in pediatric patients in United States hospitals: epidemiology, clinical features and susceptibilities. Pediatr Infect Dis J. 2003; 22(8): 686 -91.

17. Ginsburg I. Role of lipoteichoic acid in infection and inflammation. Lancet Infect Dis. 2002; 2(3): 171-179.

18. Yang S, Tamai R, Akashi S, Takeuchi O, Akira S, Sugawara S, et al. Synergistic effect of muramyldipeptide with lipopolysaccharide or lipoteichoic acid to induce inflammatory cytokines in monocytic cells in culture. Infect Immun. 2001; 69(4): 2045-53.

19. Bhakdi S, Klonisch T, Nuber P, Fischer W. Stimulation of monokine production by lipoteichoic acids. Infect Immun. 1991; 59(12): 461420.

20. Henderson B, Wilson M. Cytokine induction by bacteria: beyond lipopolysaccharide. Cytokine. 1996; 8(4): 269-82.

21. Bab I, Sela MN, Ginsburg I. Inflammatory lesions and bone resorption induced in the rat periodontium by lipoteichoic acid of Streptococcus mutans. Inflammation. 1979; 3(4): 45-58.

22. Matsuguchi T, Takagi A, Matsuzaki T, Nagaoka M, Ishikawa $\mathrm{K}$, Yokokura T, et al. Lipoteichoic acids from Lactobacillus strains elicit strong tumor necrosis factor alpha-inducing activities in macrophages 
through Toll-like receptor 2. Clin Diagn Lab Immunol. 2003; 10(2): 259-66. doi: 10.1128/CDLI.10.2.259-266.2003.

23. Wang PL, Shirasu S, Daito M, Ohura K. Streptococcus mutans lipoteichoicacid induced apoptosis in cultured dental pulp cells from human deciduous teeth. Biochem Biophys Res Commun. 2001; 281(4): 957-61.

24. Botero TM, Mantellini MG, Song W, Hanks CT, Nor JE. Effect of lipopolysaccharides on vascular endothelial growth factor expression in mouse pulp cells and macrophages. Eur J Oral Sci. 2003; 111(3): $228-34$.

25. Telles PD, Hanks CT, Machado MA, Nor JE. Lipoteichoic acid upregulates VEGF expression in macrophages and pulp cells. J Dent Res. 2003; 82(6): 466-70.

26. Horiba N, Maekawa Y, Abe Y, Ito M, Matsumoto T, Nakamura H. Correlations between endotoxin and clinical symptoms or radiolucent areas in infected root canals. Oral Surg Oral Med Oral Pathol. 1991; 71(4): 492-95.

27. Jacinto RC, Gomes BP, Shah HN, Ferraz CC, Zaia AA, Souza-Filho FJ. Quantification of endotoxins in necrotic root canals from symptomatic and asymptomatic teeth. J Med Microbiol. 2005; 54(8): 777-83.

28. MolanderA, Reit C, DahlenG, Kvist T. Microbiological status of rootfilled teeth with apical periodontitis. Int Endod J. 1998; 31(1):1-7.

29. Murakami Y, Hanazawa S, Tanaka S, Iwahashi H, Yamamoto Y, Fujisawa S. A possible mechanism of maxillofacial abscess formation: involvement of Porphyromonasendodontalis lipopolysaccharide via the expression of inflammatory cytokines. Oral Microbiol Immunol. 2001; 16(6): 321-5

30. Gutsmann T, Muller M, Carroll SF, Mackenzie RC, Wiese A, Seydel U. Dual Role of Lipopolysaccharide (LPS)-Binding Protein in Neutralization of LPS and Enhancement of LPS-induced Activation of Mononuclear Cells. Infect Immun. 2001; 69(11): 6942-6950.

31. Tietze K, Dalpke A, Morath S, Mutters R, Heeg K, Nonnenmacher C.
Differences in innate immune responses upon stimulation with grampositive and gram-negative bacteria. J Periodontal Res. 2006; 41(5): 447-54.

32. Durand SH, Flacher V, Romeas A, Carrouel F, Colomb E, Vincent C, et al. Lipoteichoic Acid Increases TLR and Functional Chemokine Expression while Reducing Dentin Formation in Odontoblasts. J Immunol. 2006; 176(5): 2880-87.

33. Adachi T, Nakanishi T, Yumato H, Hirao K, Takahashi K, Mukai K, et al. Caries-related bacteria and cytokines induce CXCL10 in dental pulp. J Dent Res. 2007; 86(12): 1217-22.

34. Staquet MJ, Durand SH, Colomb E, Romeas A, Vincent C, Bleicher F, et al. Different roles of odontoblasts and fibroblasts in immunity. J Dent Res. 2008; 87(3): 256-61.

35. Baik JE, Ryu YH, Han JY, Im J, Kum KY, Yun CH, et al. Lipoteichoic acid partially contributes to the inflammatory response to Enterococusfaecalis. J Endod. 2008; 34(8):975-82. doi: 10.1016/j. joen.2008.05.005.

36. Soden RI, Botero TM, Hanks CT, Nor JE. Angiogenicsignaling triggered by cariogenic bacteria in pulp cells. J Dent Res. 2009; 88(9): 835-40.

37. Kraus D, Winter J, Jepsen S, Jäger A, Meyer R, Deschner J. Interactions of adiponectin and lipopolysaccharide from Porphyromonas gingivalis on human oral epithelial cells. PLoS One. 2012; 7(2): e30716. doi: 10.1371/journal.pone.0030716.

38. Maciel KF, Neves De Brito LC, Tavares WL, Moreira G, Nicoli JR, Vieira LQ, et al. Cytokine expression in response to root canal infection in gnotobiotic mice. Int Endod J. 2012; 45(4): 354-62. doi: 10.1111/j.1365-2591.2011.01983.x.

39. Siqueira JF, Rocas IN. Bacterial pathogenesis and mediators in apical periodontitis. Braz Dent J. 2007; 18(4): 267-80.

40. Dewhirst FE, Chen T, Izard J, Paster BJ, Tanner AC, Yu W, et al. The Human Oral Microbiome. J Bacteriol. 2010; 192(19): 5002-17. 